\title{
THE ROLE OF WORK MOTIVATION TO IMPROVE QUALITY OF GOVERNMENT SERVICES
}

\author{
Ahmad Afan Zaini \\ University Of Merdeka Malang \\ Indonesia \\ Anwar Sanusi \\ University Of Merdeka Malang \\ Indonesia \\ Harsono \\ University Of Merdeka Malang \\ Indonesia
}

\section{ABSTRACT}

Quality of service is the superiority of services provided by a person or service provider to meet the needs and expectations of service users. Service quality indicators used to measure it are Manifestation, reliability, responsiveness, assurance, and empathy. This research uses a quantitative design approach to answer the problem formulation and proof of the research hypothesis. The study aims to analyze the influence of exogenous variables, namely transformational leadership, competence, and work environment on endogenous variables, namely service quality through intervening variables, namely work motivation. The conceptual framework of the research underlies the submission of the research hypotheses. Measurement instruments are given to the sample to obtain research variable data. Research data were analyzed using Structural Equation Modeling (SEM) to test hypotheses. This study uses a correlational research survey design. This study's population is the apparatus (employees) in the Regional Government of Tuban Regency as many as 155 . The results of this study are as follows: Transformational Leadership, Competence, and Work Environment have a significant effect on the Work Motivation of the Tuban Regency Regional Government Apparatus. Transformational Leadership, Competence, and Work Environment have a significant effect on the Service Quality of the Tuban District Government Apparatus Services. Work Motivation has a significant effect on the Service Quality of the Tuban Regency Regional Government Apparatus. Transformational Leadership, Competence, and Work Environment have a significant effect on the Service Quality of the Tuban Regency Government Apparatus through Work Motivation.

\section{KEYWORDS: Transport policy, sustainable transport, cycling, ethnograph transformational leadership, competence, work environment, work motivation, service quality.}

\section{Introduction}

Regional autonomy, which is a requirement with strategic issues in the form of institutions, human resources in the form of implementing apparatuses, networks, and conducive environment that continues to change, is a challenge for the implementing apparatus, which is the spearhead in providing services to the community. As a public sector organization, the local government is oriented to the public interest, which is not profit-oriented as the ultimate goal. Service is an activity, product, and intangible service that cannot be owned does not last long but is experienced and felt by service recipients (Kristiono, 2015: 139).

To get a proper assessment of service, the apparatus must master five elements: fast, precise, friendly, neat, and comfortable (Kristiono, 2015:33). The five elements are the main requirements that must be owned by the local government apparatus so that there is a good relationship between the people who need services from the local government officials so that the community is satisfied with the services of the apparatus received. For this reason, the government bureaucracy apparatus, particularly the Heads of Regional Apparatus Organizations (OPD), has leadership, competence, motivation, and responsibility as well as accountability in carrying out their duties and functions as an element of service to public organizations. This is very important for bureaucrats in carrying out the mission of their duties to realize the goal towards success, namely in the form of excellent service quality so that it can meet the community's needs and desires. Therefore Pasolong (2003:178) states that bureaucratic performance can be measured by productivity, 


\section{CCenter for Promoting Education and Research (CPER) USA wwww.cpernet.org}

service quality, responsiveness, responsibility, accountability.

\subsection{Research purposes}

The research objectives are as follows, describe transformational leadership, competence, work environment, service quality, and work motivation of the Tuban district government apparatus.

We are analyzing the effect of transformational leadership, competence, and work environment, on the work motivation of the Tuban district government apparatus.

Analyzing the effect of transformational leadership, competence and work environment on the quality of service of the Tuban district government apparatus, analyzing the effect of work motivation on the quality of service of the Tuban district government apparatus, analyzing the effect of transformational leadership, competence and work environment on service quality through the work motivation of the Tuban district government apparatus.

\subsection{Hypothesis}

The hypotheses in this study are as follows:

H1. Transformational leadership, competence, and work environment significantly influence the work motivation of the Tuban district government apparatus. H2. Transformational leadership, competence, and work environment significantly influence the service quality of the Tuban district government apparatus.

H3. Work motivation has a significant effect on the quality of service of the Tuban district government apparatus.

H4. Transformational leadership, competence, and work environment significantly influence the service quality of the Tuban district government apparatus through work motivation.

\section{Literature Review}

Quality of service is the superiority of services provided by a person or service provider to meet the needs and expectations of service users (Zeithaml et al., 2003:14). Parasuraman (1999:18) service quality compares perceived service (perception) of consumers with the service quality expected by consumers. Similarly, Gronroos (2001:36) stated that as a perceived between what is expected and what is delivered. Lovelock (1992:88) defines the quality of service is an effort to meet the needs coupled with the desires of consumers and the accuracy of the way they are delivered to meet customer expectations. Indicators of service quality are Manifestation, reliability, responsiveness, assurance, and empathy.

Work motivation is the strength or desire to achieve someone as a need or needs that encourage, direct, and move to behave and behave to achieve goals (Mc Clelland, 1987:81). Work motivation is an encouragement that encourages someone to do a good job (Moon, 1993:359). Likewise,
Gibson (1992:45) argues that work motivation is a force that drives, directs, and moves individuals to behave and behave to achieve goals. Indicators of work motivation are needs for achievement, needs for power, and needs for affiliation.

Transformational leadership is a leader who inspires followers or subordinates to transcend self-interest and can influence profoundly to subordinates (Robbins, 2016:65). According to Yukl (2010:296), transformational leadership creates success in achieving an organization's goals, increasing organizational commitment, and improving the process of achieving other organizational goals. Transformational leadership can increase subordinates' awareness by encouraging higher ideals and moral values such as independence, justice, equality, peace, and a sense of humanity, rather than arousing emotional attitudes such as fear, greed, jealousy, or hatred. Furthermore, Sashkin and Sashkin (2011:24) say that transformational leadership, in principle, motivates subordinates to do better than what can be done. In other words, there is an increase in low confidence or self-confidence that will affect service quality. Indicators of transformational leadership are: challenging processes, enabling others, exemplary, and encouraging.

Competence is an essential characteristic of someone that influences the way of thinking and acting, making generalizations about all situations encountered, and lasts long enough in human beings (Ruky, 2003:26). Armstrong (2004: 189) said that competence is knowledge, skills, and individual quality to achieve the success of his work. Competence is an essential characteristic of individual behavior related to the criteria of reference and or superior performance in a job or situation (Sudarmanto, 2009: 46). Boulter (1996: 36) says that competence is a variety of technical and non-technical factors, personality and behavior, soft skills and hard skills, which are used as aspects assessed by many companies to recruit employees into the organization. The competency indicators are character, attitude and values, skills, and knowledge.

The work environment is factors outside of humans, both physical and non-physical in an organization (Terry, 2006:23). These physical factors include work equipment, the temperature in the workplace, crowding and density, noise, and workspace. In contrast, non-physical includes work relationships formed in the institution between superiors and subordinates as well as between fellow employees. Simamora (2001:62) says that the working environment is divided into two, namely the physical environment, which includes ventilation, workspace lighting, workspace management, and work equipment; and psycho-social or treatment received, which includes social interactions at work that can affect the existence of a positive response. Subroto (2005: 38) states that the work environment is a condition around the workplace both physically and nonphysically that can give a pleasant impression, secure, reassuring, and comfortable at work. Work environment 


\section{(C) Center for Promoting Education and Research (CPER) USAwww.cpernet.org}

indicators are physical work environment and non-physical work environment.

\section{Research Method}

\section{Research sites}

This research was conducted in the Tuban Regency local government (panda) because Tuban Regency is one of the regencies in East Java who became a pilot project of the Ministry of Administrative Reform and Bureaucracy Reform (Kemenpan RB) in terms of performance accountability. To improve performance achievements is to create a bureaucratic reform index, which will focus on measuring performance at every level of the government apparatus. The measurement is carried out starting from the planning stage, improving local government public services' performance, with a minimum target of giving good value to the public satisfaction of the services performed by local governments in each community service unit.

\section{Population}

This study population is the leadership element OPD (Regional Apparatus Organization) in the Regional Government of Tuban Regency. OPD referred to in this study consists of agencies and agencies that provide direct services to the community. 31 Regional OPDs in the Tuban Regency Government are 31. The target population in this study is the Head of the Office and the Head of the Agency, along with the Division Head in all OPDs in the Tuban Regency Government as many as 155 people.

\section{Data analysis technique}

The data in this study will be analyzed descriptively using SPSS 20 and SEM applications. Descriptive data to determine the description of research data, including average score scores, mean score of indicators and mean of transformational leadership variables, competence, work environment, work motivation, and service quality. SEM was developed based on research variables, namely transformational leadership, competence, and work environment, as exogenous variables (dependent variable).

The model was developed as a result of a literature study on causal relations, both theoretical and empirical, from the support of previous studies. SEM is used to confirm theoretical models based on empirical data from research results. Each variable is examined for understanding and indicators to find causality relationships between variables so that the theoretical model's accuracy can be tested based on empirical data.

\section{Results \& Discussion}

A validity test is done to determine whether the measuring instrument that has been compiled can be used to measure what is being measured precisely. Test the validity of each question in this study using the product-moment correlation formula from Pearson. The validity test results for each variable are as follows: The results of the Transformational Leadership variable validity test showed that each indicator of the research variable produced an $r$ count greater than the $r$ table value (0.159). The results of the validity test of the Service Quality variable indicate that each indicator of the research variable produces an $r$ count value higher than the $r$ table value $(0.159)$ or a probability value smaller than 0.05 so that it can be concluded that all items/indicators are valid which means it is a tool that right to take measurements on the variable Service Quality.

The indicator has been tested for validity, the next question is to measure whether the indicator produces a reliable or consistent measurement. To answer this question, reliability testing was performed using Cronbach's Alpha. The reliability test results of each variable area in the following Table 1:

Table 1 Reliability Test Results

\begin{tabular}{lcccc}
\hline \multicolumn{1}{c}{ Variable } & $\begin{array}{c}\text { Number of } \\
\text { Instruments }\end{array}$ & $\begin{array}{c}\text { Alpha } \\
\text { Cronbach }\end{array}$ & Label & Results \\
\hline Transformational Leadership & 8 & 0.727 & 0.600 & Reliable \\
Competence & 13 & 0.728 & 0.600 & Reliable \\
Work Environment & 10 & 0.774 & 0.600 & Reliable \\
Work Motivation & 15 & 0.862 & 0.600 & Reliable \\
Quality Of Service & 18 & 0.738 & 0.600 & Reliable \\
\hline
\end{tabular}

Source: Primary data processed

Reliability testing is done by comparing the Alpha Cronbach calculation results with a reference value of 0.6. Based on the results of the Alpha Cronbach test on each research variable, it appears that the Cronbach Alpha value of all research variables is more significant than 0.6 . It can be concluded that the measurement is reliable or consistent.

\section{Descriptive Analysis}

This descriptive analysis was conducted to obtain a description of respondents 'answers regarding the variables examined in this study which were conducted by analyzing the frequency of respondents' answers on each indicator.

\section{Variable}

Description of the Transformational Leadership

The Transformational Leadership Variable with Challenging Process indicators is 3,936, Enabling Others is 


\section{(C) Center for Promoting Education and Research (CPER) USAwww.cpernet.org}

3,823, Exemplary is 3,939, and Encouraging is 4,068. The mean value of Transformational Leadership is 3,942, meaning that the Transformational Leadership variable in the Tuban District Government agrees that it is explained by indicators of Challenging Processes, Enabling Others, Exemplary, and Encouraging. The Encouraging Indicator has the highest average of 4,068 compared to other indicators. This shows that respondents strongly agree that the Indicator Encouraging is the main factor explaining Transformational Leadership. Indicators of Encouragement are measured based on the Chair conducting direction in completing the work done by subordinates. Leadership directives demonstrate integrity among various interests and can motivate subordinates to complete tasks.

\section{Description of Competency Variables}

The Competence Variable with the Character indicator is 4,315, Attitude and Value is 4,236, Skill is 4,205, and knowledge is 4,182 . The mean value of competence is 4,236 . This means that the Competency variable in the Tuban District Government strongly agrees to be explained by the indicators of Character, Attitude and Values, Skills, and Knowledge. The Character Indicator has the largest average of 4,315 compared to other indicators. This shows that the respondents strongly agree that the Character indicator is the main factor explaining Competency. The Character Indicator is measured on the basis that Employees will work sincerely. Working sincerely shows integrity among various interests, and can motivate subordinates to provide quality services in carrying out tasks.

\section{Description of Work Environment Variables}

Work Environment Variable with indicators Physical Work Environment of 4,288, and Non-Physical Work Environment of 4,339. The mean value of the Work Environment is 4,314, meaning that the Work Environment variable in the Tuban District Government strongly agrees explained by indicators of the Physical Work Environment and Non-Physical Work Environment. Non-Physical Work Environment Indicators have a broad average of 4,339 compared to other indicators. This shows that respondents strongly agree that the Non-Physical Work Environment indicator is the main factor explaining the Work Environment. Non-Physical Work Environment Indicators are measured based on at workplaces, and there is clarity of work structure. The clarity in work structure can motivate subordinates to provide quality services in carrying out tasks.

\section{Description of Work Motivation Variables}

Work Motivation Variable with Achievement Needs indicator of 4,346, Power Needs of 4,077, and Affiliated Needs of 4,179. The mean value of Work Motivation is 4,201 , meaning that the variable of Work Motivation in the Tuban District Government strongly agrees explained by indicators of Achievement Needs, Power Needs, and Affiliated Needs. The Achievement Needs Indicator has the largest average of 4,346 compared to other indicators. This shows that respondents strongly agree that the Indicator of Achievement Needs is the main factor explaining Work Motivation. Indicators of Achievement Needs are measured based on Enjoying satisfaction from completing work assignments. Enjoying the satisfaction of completing tasks shows integrity among various kinds of interests, and can motivate subordinates to provide quality services in carrying out tasks.

\section{Description of Service Quality Variables}

Service Quality Variable with the indicators of realization is 4,503 , reliability is 4,324 , responsiveness is 4,363 , a guarantee is 4,337 , and empathy is 4,271 . The mean value of Service Quality is 4,306, meaning that the Service Quality variable in the Tuban District Government strongly agrees to be explained by indicators of Manifestation, Reliability, Responsiveness, Assurance, and Empathy. The Indicator of Realization has the largest average of 4,503 compared to other indicators. This shows that the respondents strongly agree that the indicator of Manifestation is the main factor explaining Service Quality. Indicators of Manifestation are measured based on the workplace, where employees look neat and professional. A neat and professional appearance shows integrity among various interests and can motivate subordinates to provide quality services in carrying out tasks.

\section{Analysis}

Results of SEM (Structural Equation Modeling)

Confirmatory factor analysis is used to measure the level of support of indicators on latent variables. In the structural equation model built, there are five latent variables and eighteen research indicators, consisting of 3 exogenous constructs with ten observed and two endogenous with eight observed. Determining the value of factor loading in structural modeling is done using the Analysis of Moment Structure (AMOS) program. The results of factor loading values in exogenous and endogenous constructs areas in Tables 2 and 3 below:

\section{Exogenous variables}

The factor loading values for each exogenous latent variable are shown in Table 2 below: 


\section{(C) Center for Promoting Education and Research (CPER) USAwww.cpernet.org}

Table 2

\section{Exogenous Constructor Loading Factor Value}

\begin{tabular}{cllc}
\hline No & \multicolumn{1}{c}{ Latin Variable } & \multicolumn{1}{c}{ Indicator } & Score \\
\hline 1. & Transformational Leadership & Challenging Process & 0.79 \\
& & Enabling Others & 0.82 \\
& & Exemplary & 0.78 \\
2. & \multirow{3}{*}{ Competence } & Encouraging & 0.77 \\
& & Walk & 0.86 \\
& & Attitudes and Values & 0.79 \\
3. & \multirow{3}{*}{ Work Environment } & Skills & 0.93 \\
& & Knowledge & 0.77 \\
& & Physical Work Environment & 0.76 \\
& & Non-Physical Work & 0.80 \\
\hline
\end{tabular}

Source: Primary data processed

Table 2 above shows that the indicators for each Transformational Leadership, Competency, and Work Environment variable have a factor loading value higher than the cut-off value of 0.5 , meaning that each of the tested indicators can reflect the measured variable. The results of the evaluation of the factor loading values for each latent variable are as follows:

The results of the factor loading evaluation are Transformational Leadership

The Transformational Leadership Variable is formed by four indicators, namely a challenging process of 0.79 , enabling others by 0.82 , an example of 0.78 , and encouraging by 0.77 . Table 2 shows that the factor loading indicator's value enables others to make a more significant contribution compared processes. This study's results indicate that indicators that enable others are the best reflection of the latent variable of Transformational Leadership.

The results of factor loading evaluation are Competency variables to indicators of challenging, exemplary, and encouraging

The Competency variable is formed by four indicators: a character of 0.86 , an attitude and value of 0.79 , a skill of 0.93 , and knowledge of 0.77 . Table 2 shows that the factor loading value of skills indicators contributed more than the indicators of character, attitudes and values, and knowledge. This study's results indicate that the skills indicator is the best reflection of the latent competency variable.

The results of the evaluation of factor loading work environment variables

The Work Environment variable is formed by two indicators: the physical work environment by 0.76 , and the non-physical work environment by 0.80 . Table 2 shows that the factor loading value of non-physical work environment indicators contributed to the physical work environment indicators. This study's results indicate that non-physical work environment indicators are the best reflection of the Work Environment variable.

\section{Endogenous variables}

The factor loading values for each endogenous latent variable are shown in Table 3.

Table 3

Value of Factor Loading Endogenous Constructions

\begin{tabular}{cllr}
\hline No & Latin Variable & Indicator & Score \\
\hline 1. & Work Motivation & Achievement Needs & 0.90 \\
& & Need For Power & 0.88 \\
\multirow{3}{*}{ 2. Service Quality } & Affiliated Needs & 0.78 \\
& & Manifestation & 0.92 \\
& & Justice & 0.94 \\
& & Date Power & 0.89 \\
& & Guarantee & 0.86 \\
& Empathy & 0.83 \\
\hline
\end{tabular}

Source: Primary data processed

Table 3 shows that the indicators of each variable Work Motivation and Service Quality have a factor loading value higher than the cut-off value of 0.5 , which means that each indicator is tested can reflect latent variables. The results of the evaluation of the factor loading values for each latent variable are as follows:

The results of factor loading evaluation are work motivation

Work Motivation Variables are formed by three indicators: the need for achievement by 0.90 , the need for power by 0.88 , and the need for affiliation by 0.78 . Table 3 shows that the value of the factor loading indicator of achievement needs contributes more than the indicators of http://dx.doi.org/10.33642/ijbass.v6n8p4 


\section{(C) Center for Promoting Education and Research (CPER) USAwww.cpernet.org}

power needs and affiliated needs. This study's results indicate that the indicator of achievement needs is the best reflection of the latent variable of Work Motivation.

\section{The results of factor loading evaluation are Service Quality variables}

The Service Quality variable is formed by five indicators: Manifestation of 0.92 , reliability of 0.94 , the responsiveness of 0.89 , guarantee of 0.86 , and empathy of 0.83 . Table 3 shows that the value of the reliability factor loading factor contributes more than the indicators of Manifestation, responsiveness, assurance, and empathy. This

Table 4

\section{Hypothesis Testing Results One}

\begin{tabular}{llll}
\hline Exogenous Variables & Endogenous Variables & $\begin{array}{l}\text { Standardized } \\
\text { Coefficient }\end{array}$ & Probability \\
\hline $\begin{array}{l}\text { Transformational } \\
\text { Leadership }\end{array}$ & Work Motivation & 0.32 & $0.000^{*}$ \\
$\begin{array}{l}\text { Competence } \\
\text { Work Environment }\end{array}$ & Work Motivation & 0.28 & $0.000^{*}$ \\
$*$ Probability Value $\leq 0.05$ & Work Motivation & 0.27 & $0.014^{*}$ \\
\hline
\end{tabular}

study's results indicate that the reliability indicator is more dominant in reflecting latent variables of Service Quality.

\section{Hypothesis test}

This study has four hypotheses to be tested, following the test results of each research hypothesis:

\section{First Hypothesis}

The first hypothesis in this study is that transformational leadership, competence, and work environment significantly influence the work motivation of the Tuban district government apparatus.

\section{Source: Primary data processed}

Based on Table 4 it shows that Transformational Based on the acquisition of the probability values of three Leadership has a coefficient of 0.32 with a probability of 0.000 exogenous variables for endogenous variables in Table 4 less than 0.05 . The results of this test indicate that informs that Transformational Leadership, Competence, and Transformational Leadership has a significant influence on Work Environment have a positive and significant effect on Work Motivation. The competency coefficient value of 0.28 , Work Motivation. Thus, the first hypothesis in this study is with a probability of 0.000 is smaller than 0.05 . The results of accepted. this test indicate that competence has a significant influence on Work Motivation. The coefficient value of the Work

\section{Second Hypothesis}

The second hypothesis in this study is that Environment is 0.27 , with a probability of 0.014 smaller than transformational leadership, competence, and work environment 0.05. The results of this test indicate that the Work significantly influence the Tuban district government Environment has a significant influence on Work Motivation. apparatus's service quality.

\section{Table 5}

\section{Second Hypothesis Testing Results Second Hypothesis Testing Results}

\begin{tabular}{llll}
\hline Exogenous Variables & Endogenous Variables & $\begin{array}{l}\text { Standardized } \\
\text { Coefficient }\end{array}$ & Probability \\
\hline $\begin{array}{l}\text { Transformational } \\
\text { Leadership }\end{array}$ & Service Quality & 0.37 & $0.000^{*}$ \\
$\begin{array}{l}\text { Competence } \\
\text { Work Environment }\end{array}$ & Service Quality & 0.20 & $0.006^{*}$ \\
$*$ *) Probability Value $\leq 0.05$ & Service Quality & 0.24 & $0.015^{*}$ \\
\hline
\end{tabular}

Source: Primary data processed

Table 5 shows that Transformational Leadership has a on Service Quality. Based on the acquisition of the probability coefficient of 0.37 with a probability of 0.000 less than 0.05 . values of the three exogenous variables for endogenous The results of this test indicate that Transformational variables in Table 5 informs that Transformational Leadership, Leadership has a significant influence on Service Quality. The Competence, and Work Environment have a positive and competency coefficient value is 0.20 , with a probability of significant effect on Service Quality. Thus, the second 0.006 smaller than 0.05 . The results of this test indicate that hypothesis in this study is accepted. competence has a significant effect on service quality. The coefficient value of the Work Environment is 0.24 , with a probability of 0.015 less than 0.05 . The results of this test indicate that the Work Environment has a significant influence

\section{Third Hypothesis}

The third hypothesis in this study is that work motivation significantly affects the quality of service of the Tuban district government apparatus. 


\section{(C) Center for Promoting Education and Research (CPER) USAwww.cpernet.org}

\begin{tabular}{lcll}
\multicolumn{4}{c}{ Table 6 } \\
& Third Hypothesis Testing Results & \\
\hline Variable Intervening & Endogenous Variables & $\begin{array}{l}\text { Standardized } \\
\text { Coefficient }\end{array}$ & Probability \\
\hline Work Motivation & Service Quality & 0.19 & $0.031^{*}$ \\
*) Probability Value $\leq 0.05$ & & & \\
\hline
\end{tabular}

Source: Primary data processed

Table 6 shows that Work Motivation has a coefficient of 0.19 with a probability of 0.031 less than 0.05 . The results of this test indicate that work motivation has a significant effect on service quality. Based on the acquisition of the variable probability of Work Motivation on Service Quality variables in Table 6 informs that Work Motivation has a

positive and significant effect on Service Quality. Thus, the third hypothesis in this study is accepted.

\section{Fourth Hypothesis}

Hypothesis four is that transformational leadership, competence, and work environment significantly affect the service quality of the Tuban district government apparatus through work motivation.

Table 7

Fourth Hypothesis Testing Results

\begin{tabular}{|c|c|c|c|c|}
\hline $\begin{array}{l}\text { Exogenous } \\
\text { Variables }\end{array}$ & $\begin{array}{l}\text { Mediation } \\
\text { Variable }\end{array}$ & $\begin{array}{l}\text { Endogenous } \\
\text { Variables }\end{array}$ & $\begin{array}{l}\text { Standardized } \\
\text { Coefficient }\end{array}$ & Probability \\
\hline $\begin{array}{l}\text { Transformational } \\
\text { Leadership }\end{array}$ & $\begin{array}{l}\text { Work } \\
\text { Motivation }\end{array}$ & Service Quality & 0.43 & $0.000^{*}$ \\
\hline Competence & $\begin{array}{l}\text { Work } \\
\text { Motivation }\end{array}$ & Service Quality & 0.26 & $0.006^{*}$ \\
\hline $\begin{array}{l}\text { Work Environment } \\
\text { *) Probability Value }\end{array}$ & $\begin{array}{l}\text { Work } \\
\text { Motivation } \\
0.05\end{array}$ & Service Quality & 0.29 & $0.015^{*}$ \\
\hline
\end{tabular}

\section{Source: Primary data processed}

\section{Limitation of Research Results}

Description of Respondent Perception results for each variable

This research is perceptional, aiming to describe the respondents' perceptions about Transformational Leadership, Competence, and Work Environment on Service Quality through Work Motivation of the Tuban District Government Apparatus. The respondents' perceptions of transformational leadership, competence, and work environment on service quality through work motivation of the Tuban Regency Regional Government apparatus are as follows:

\section{a. Transformational leadership}

Transformational leadership is shaped by processes that challenge, empower others, set an example, and encourage. The results showed that encouragement was a significant factor in transformational leadership in the Tuban District Government compared to a challenging process, enabling others, and example. Encouraging is practiced with the leadership conducting directions in completing the work done by subordinates and willing to accept input from subordinates.

The findings of this study support the theory conveyed by Robbins (2016) that transformational leadership inspires followers or subordinates to transcend self-interest and can profoundly influence the people by providing direction in completing work done by subordinates. Yukl (2010) that transformational leadership is first directed at the interests of subordinates. Here, the leader's main interest is to improve the conditions of subordinates out of a state of deterioration towards better conditions. Thus, the measurement of transformational leadership proposed by Robbins (2016) can contribute to this research. This means that the components of the process that are challenging, enabling others, exemplary, and encouraging can be applied in the Tuban district government.

\section{b. Competence}

Perceptions about employee competencies are shaped by character, attitude and values, skills, and knowledge. The results showed that character is the primary constructor of competence in the District Government of Tuban compared to attitudes and values, skills, and knowledge. Characteristics practiced by employees will work with sincerity, responsibility in work given, and confidence in completing workloads.

The findings of this study support the theory conveyed by Ruky (2003) that competencies are all forms of expression, expression, and representation of the main motives, knowledge, attitudes, behaviors to be able to carry out work very well or differentiate between average performance and superior performance. Ruky's (2003) 's measurement of competence, which includes character, attitude, and values, skills, and knowledge, can be tested in this study. This means that 


\section{CCenter for Promoting Education and Research (CPER) USA wwww.cpernet.org}

Competency is measured by character, attitude, and values, skills, and knowledge that can be applied in the Tuban District Government.

\section{c. Work environment}

The work environment in this study was shaped by the physical work environment and the non-physical work environment. The results showed that the non-physical work environment was the leading maker of the Tuban District Government's work environment compared to the physical work environment. The non-physical work environment is applied where there is clarity in the work structure, in the workplace, there is communication between groups, in the workplace, the leadership pays attention to employee work difficulties, at work, the employees have their respective responsibilities, and at work creates cooperation between groups.

The findings of this study support the theory and measurement proposed by Terry (2006) and Simamora (2001), which explain that the work environment is factors outside of humans both physical and non-physical in an organization. These physical factors include work equipment, the temperature in the workplace, crowding and density, noise, workspace area. In contrast, non-physical includes work relationships that are formed in the institution between superiors and subordinates as well as between fellow employees. Thus, the measurement of the work environment proposed by Terry (2006) can be tested in this study, meaning that the work environment measured through the physical work environment and non-physical work environment can be applied in the Regional Government of Tuban Regency.

\section{d. Work motivation}

Employees' work motivation in the Tuban District Government is reflected by the need for achievement, the need for power, and the need for affiliation. This study's results indicate that the need for achievement is a significant factor in shaping employee work motivation in the Tuban District Government compared to the need for power and affiliated needs. Achievement needs are applied through enjoying the satisfaction of completing work assignments, having a strong need to achieve goals at work, calculating risks while completing work assignments, having severe efforts to improve performance, and setting realistic goals at work.

This study's findings support the theory and measurement proposed by Mc Clelland (1987) and Gibson (1992). They explain that work motivation is a force that drives, directs, and moves individuals to behave and behave to achieve goals. Thus, the measurement of work motivation proposed by Mc Clelland (1987) and Gibson (1992) can be tested in this study, meaning that employee work motivation as measured through the need for achievement, affiliation needs, and power needs can be applied in the Tuban District Government.

\section{e. Service quality}

The quality of service in the Tuban District Government is formed by Manifestation, reliability, responsiveness, assurance, and empathy. The study results showed that Manifestation was the primary shaper of service quality in the Tuban District Government compared to responsiveness, assurance, reliability, and empathy. The realization in the Regional Government of Tuban Regency is applied through the workplace of employees who look neat and professional. The workplace has physical facilities that look attractive and have modern equipment.

The results of this study support the theory put forward by Zeithaml et al. (2003) and Gronroos (2001). They state that service quality is a service advantage provided by a person or service provider to meet the needs and expectations of service users. Thus, the measurement of service quality proposed by Zeithaml et al. (2003) can be tested in this study, meaning that the quality of services measured through Manifestation, reliability, responsiveness, assurance, and empathy can be applied in the Regional Government of Tuban Regency.

1. Transformational leadership, competence, and work environment significantly affect the work motivation of the Tuban District Government apparatus.

Transformational leadership, competence, and work environment provide an increase in the work motivation of the Tuban District Government apparatus. Transformational leadership has a dominant influence on work motivation compared to competence and work environment. Shown by factors enabling others to be reflected through the leadership is a source of inspiration in working and supporting subordinates in their development. Therefore, if the Tuban District Government wants to increase work motivation, employees must pay attention to transformational leadership factors, competencies, and work environment.

2. Transformational leadership, competence, and work environment significantly affect the quality of service of the Tuban Regency Government.

Transformational leadership, competence, and work environment provide an increase in the Tuban Regency Regional Government apparatus's quality of service. Transformational leadership has a more dominant influence compared to competence and work environment to improve service quality.

3. Work motivation has a significant effect on the service quality of the Tuban Regency Regional Government apparatus.

Work motivation, which means they need achievement by enjoying the satisfaction of completing work tasks, has implications for improving the quality of service of employees in completing work.

4. Transformational leadership, competence, and work environment significantly affect the quality of service of the Tuban District Government apparatus through work motivation. 


\section{CCenter for Promoting Education and Research (CPER) USA wwww.cpernet.org}

The quality of employee services reflected by the Tuban District Government apparatus includes; Manifestation, reliability, responsiveness, assurance, and empathy. Reliability is a dominant factor formed by providing services as promised, trained to have good knowledge, can be relied on in handling service issues, and providing services properly for the first time. Employees in carrying out their duties pay attention to reliability and refer to the vision and mission set forth by the Tuban District Government.

Based on the previous discussion, namely, the first discussion stated that transformational leadership, competence, and work environment could increase work motivation. When looking at the results of a comparison between total influence with direct influence, it can be seen that transformational leadership, competence, and work environment have a higher total effect than direct influence. This explains that transformational leadership, competence, and work environment can influence service quality through work motivation. Thus, in this discussion, work motivation could mediate transformational leadership, competence, and work environment to improve the quality of service of the Tuban Regency Regional Government apparatus.

\section{Conclusion}

Transformational leadership, competence, and work environment significantly influence the work motivation of the Tuban District Government apparatus. Transformational leadership, competence, and work environment have a significant effect on the quality of service of the Tuban District Government apparatus, work motivation has a significant effect on the service quality of the Tuban Regency Regional Government apparatus, transformational leadership, competence and work environment have a significant effect on service quality through the work motivation of the Tuban District Government apparatus.

Based on the discussion of the results of research on transformational leadership, competence, and work environment affect the quality of service through work motivation, researchers provide the following advice: For Science, it should be considered that the results of this study can be further developed, especially in the development of human resource management science. Declining quality of service can be influenced by transformational leadership, competence, work environment, and work motivation. For Practitioners, considering that transformational leadership, competence, work environment, and work motivation can affect the service quality of the Tuban District Government apparatus, the Tuban District Government should be able to apply the indicators of these variables well. Especially in the transformational leadership variable, which is the dominant variable, is determined by memapukan other people who are reflected by the leadership is a source of inspiration in working and supporting subordinates in developing themselves. This means that the Tuban Regency Government leaders continue to maintain this conducive situation, namely the leader being a source of inspiration in working and supporting subordinates in developing themselves so that employees can carry out their duties and responsibilities properly.

\section{Reference}

Armstrong, Michael dan Baron, A. 2004. Performance Management: The New Realities. New York: Institute of Personnel and Development.

Boulter, N.M. Dalziel dan Jackie 1996. People and Competence: The Route to Competitive Advantage. London: McGraw-Hill. Gibson, Ivan Ceviche, and Donelly, 1992. Organizational Behavior Structure Processes. New York: McGraw-Hill/Irwin.

Gronroos, C. dan J. Edvardsson. 2001. Service Management and Marketing: Managing the Moment of in Service Competition. Lexington: Massachusetts.

Kristiono, Mardikanto. 2015. Peningkatan Kualitas Pelayanan Publik. Jakarta: Gramedia.

Lovelock H, Christopher. 1992. Managing Service: Marketing, Operations, and Human Resources. Second Edition. New Jersey: Prentice-Hall, Englewood Cliffs.

Mc Clelland, D.C. 1987. Human Motivation. New York: The Press Syndicate of the University of Cambridge.

Moon, P. 1993. The Motivation to Work and Work-Related Attitudes and Motivation, Industrial-Organizational Psychology. New York: McGraw-Hill/Irwin.

Pasolong. 2003. Kepemimpinan Birokrasi. Bandung: CV Alfabeta.

Robbins, Stephen P. dan Timothy A. Judge. 2016. Organizational Behavior. 16th ed. New Jersey: Pearson Education, Inc.

Ruky, Achmad S. 2003. Sumber Daya Manusia Berkualitas Mengubah Visi Menjadi Realitas. Jakarta: PT. Gramedia Pustaka Utama.

Sashkin, Marshal dan Molly G. Sashkin. 2011. Leadership That Matters. Penerjemah Rudolf Hutauruk. Jakarta: Penerbit Erlangga. 


\section{(C) Center for Promoting Education and Research (CPER) USA www.cpernet.org}

Simamora, Henry. 2001. Human Resources Management. New Jersey: Prentice-Hall.

Subroto. 2005. Manajemen Sumber Daya Manusia. Jakarta: Alex Media Kompetindo.

Sudarmanto. 2009. Kinerja dan Pengembangan Kompetensi SDM. Yogyakarta: Pustaka Pelajar.

Terry, George Robert. 2006. Principles of Management. Homewood: Irwin, Michigan University.

Yukl, Gary. 2010. Leadership in Organizations. Seventh Edition. Upper Saddle River. New Jersey: Prentice-Hall.

Zeithaml, V. A., A. Parasuraman, et al. 2003. Delivering Quality Service: Balancing Customer Perceptions and Expectations. New York: The Free Press.

Zeithaml, V. A., A. Parasuraman dan Berry, L. L. 1999. "Servqual: A Multiple Item Scale for Measuring Consumer Perceptions of Service Quality." Journal of Retailing. Vol. 64, No. 1:12-40. 